\title{
Structure and variation of human ribosomal DNA: molecular analysis of cloned fragments
}

(Recombinant DNA; moderately repetitive DNA: DNA polymorphism; rRNA processing; R-loops)

\author{
J.M. Erickson *, C.L. Rushford **, D.J. Dorney **, G.N. Wilson ** and R.D. Schmickel *,** \\ * Department of Human Genetics and ** Department of Pediatrics, University of Michigan School of Medicine, Ann Arbor, MI \\ 48109 (U.S.A.)
}

(Received June 8th, 1981)

(Accepted July 23rd, 1981)

\section{SUMMARY}

Eco-RI-A fragments of the human ribosomal RNA gene family from two types of tissue and three individuals were cloned in $\lambda$ vectors and compared by restriction enzyme digestion and electron microscopy. The $E c o$ RI fragment A contains (i) $0.2 \mathrm{~kb}$ of the $3^{\prime}$ end of the $18 \mathrm{~S}$ rDNA, (ii) $2.5 \mathrm{~kb}$ of internal transcribed spacer and the $5.8 \mathrm{~S}$ rDNA, and (iii) $4.6 \mathrm{~kb}$ of the $28 \mathrm{~S}$ rDNA gene. All of the six cloned rDNA fragments isolated are identical by these analyses. Moreover, all contain a Hincll site that is absent in about $50 \%$ of the rDNA identified by genomic blotting. Polymorphism in the nontranscribed spacer rDNA was studied on genomic blots of BamHI-digested DNA, using the $3^{\prime}$ end of the $28 \mathrm{~S}$ rDNA as a probe. The boundaries between the $18 \mathrm{~S}$ rDNA, internal transcribed spacer, 28S rDNA, and external nontranscribed spacer were determined by R-loop analysis, further defining the organization of the ribosomal RNA precursor.

\section{INTRODUCTION}

The DNA sequences for eukaryotic ribosomal RNA (rRNA) constitute a moderately repetitive family of genes which vary in structure and organization among species (for review see Long and Dawid, 1980). In humans, the 5S ribosomal DNA (rDNA) is found on chromosome 1 (Steffensen and Duffey, 1974), while the $45 \mathrm{~S}$ precursor for the $28 \mathrm{~S}, 18 \mathrm{~S}$ and

\footnotetext{
Reprint requests should be mailed to Dr. R.D. Schmickel at Department of Pediatrics, K2015 Holden Building, University of Michigan, Ann Arbor, MI 48109 (U.S.A.).

Abbreviations: hp, base pairs; dNTPs, deoxynucleoside triphosphates; DTT, dithiothreitol; EtBr, ethidium bromide; $\mathrm{kb}$, kilobase pairs; SDS, sodium dodecyl sulfate; SSC, $0.15 \mathrm{M}$ $\mathrm{NaCl}, 0.015 \mathrm{M} \mathrm{Na} \cdot$ citrate, $\mathrm{pH} 7.6$.
}

5.8S rRNAs is transcribed from DNA arranged as tandemly repeating units (Wellauer and Dawid, 1973) in the nucleolar organizer regions of the five acrocentric chromosome pairs, Nos. 13, 14, 15, 21 , 22 (Henderson et al., 1972). There are approx. 160 of these repeat units per haploid genome (Schmickel, 1973). This family of genes is of special interest since it contains both highly conserved transcribed sequences and variable nontranscribed spacer regions (Krystal and Arnheim, 1978; Schmickel et al., 1980). Structural studies of a polymorphism seen in the length of nontranscribed spacer rDNA for both humans and apes suggest that there may be genetic exchanges between rDNA sequences found on nonhomologous chromosomes (Arnheim et al., 1980a). An analysis of independently cloned rDNA fragments 
reveals the extent to which homology is maintained among gene copies (Wilson et al., 1978; 1981). Moreover, the repetitive nature of ribosomal genes allows for a comparison of cloned fragments between individuals and also within the same individual. Examination of the gene and flanking spacer DNA permits identification of the genetic regions involved in the processing of 45S rRNA (see Perry, 1976, for a review of rRNA processing). Thus, rDNA is useful in the study of interchromosomal recombination, evolutionary variation and conservation, and rRNA transcription and processing.

Here we report the detailed structure of cloned portions of human IDNA in which we have localized the $3^{\prime}$ end of the $18 \mathrm{~S}$ rDNA, the 5.8S rDNA, and all of the 28S rDNA. In addition, we compare the rDNA EcoRI-A fragments from six independently isolated clones, representing DNA from two tissues and three individuals. Cloning of the human rDNA Eco RI fragment $B$, which contains the promoter region and the $5^{\prime}$ portion of the $18 \mathrm{~S}$ rDNA, has been previously reported by our laboratory (Wilson et al., 1978). We now have clones representing the complete length of the transcribed rDNA.

\section{MATERIALS AND METHODS}

\section{(a) Human DNA}

Human DNA was prepared from fetal human liver or from frozen placental tissue as previously described (Schmickel, 1973). DNA was enriched approx. 100 -fold for ribosomal sequences by density gradient centrifugation (Schmickel and Knoller, 1977; Wilson et al., 1978).

\section{(b) Phage $\lambda$ vector DNA}

$\lambda$ Charon 16A was grown in $E$. coli K802 (Blattner et al., 1977), and $\lambda g t W E S \cdot \lambda \mathrm{B}^{\prime}$ (Leder et al., 1977) in $E$. coli LE392. Phage DNA was prepared as described by Tiemeier et al. (1977).

\section{(c) Ligation and transfection of recombinant $\lambda$ DNA}

Both $\lambda$ vector DNAs were digested with $E c o$ RI for the insertion of EcoRI-digested human DNA. $\lambda \mathrm{gt} W E S \cdot \lambda \mathrm{B}^{\prime}$ DNA was also digested with $S s t \mathrm{I}$, which cuts twice in the middle Eco RI fragment and reduces re-ligation of parental phage DNA. $0.5 \mu \mathrm{g}$ of digested lambda DNA was mixed with $0.15 \mu \mathrm{g}$ of digested human DNA in a total volume of $50 \mu \mathrm{l}$ containing $66 \mathrm{mM}$ Tris $\cdot \mathrm{HCl} \mathrm{pH} 7.4,10 \mathrm{mM} \mathrm{MgCl}_{2}, 10$ $\mathrm{mM}$ DTT, $0.1 \mathrm{M} \mathrm{ATP}$, and 0.5 units of T4 DNA ligase. After incubation at $4^{\circ} \mathrm{C}$ for $16 \mathrm{~h}, 1 \mu \mathrm{l}$ of the ligated DNA was mixed with $0.2 \mathrm{ml}$ of calciumshocked $E$. coli cells which were then held at $42^{\circ} \mathrm{C}$ for 2 min, chilled on ice, and plated on NZY agar as previously described (Wilson et al., 1978).

\section{(d) Hybridizations and autoradiography}

DNA bound to nitrocellulose filters (Southern, 1975) was hybridized to ${ }^{125}$ I-labeled $28 \mathrm{~S}$ rRNA (Wilson et al., 1978) or to ${ }^{32}$ P-labeled cloned rDNA, nick translated to $10^{8} \mathrm{cpm} / \mu \mathrm{g}$ (Rigby et al., 1977). Filters hybridized to DNA probes were first prehybridized for $4 \mathrm{~h}$ at $65^{\circ} \mathrm{C}$ in $3 \times \mathrm{SSC}, 0.1 \% \mathrm{SDS}$, $25 \mu \mathrm{g} / \mathrm{ml}$ salmon sperm DNA and $0.02 \%$ each polyvinyl-pyrrolidone, Ficoll-400, and bovine serum albumin (Denhardt, 1966). Hybridization was in the same solution, with $10^{5} \mathrm{cpm} / \mathrm{ml}$ of $\left[{ }^{32} \mathrm{P}\right] \mathrm{rDNA}$, at $65^{\circ} \mathrm{C}$ for $12-24 \mathrm{~h}$. After rinsing in $2 \times \mathrm{SSC}, 0.5 \%$ SDS, filters were dried and exposed with XR5 Royal XOmat film (Kodak) at $-70^{\circ} \mathrm{C}$ for $12-72 \mathrm{~h}$ in the presence of a fluorescent intensifier screen.

\section{(e) Subcloning of rDNA in plasmid vectors}

The 7.3-kb Eco RI fragment A was subcloned in the plasmid pBR322 (Bolivar et al., 1977) by digestion of DNAs with EcoRI, with BamHI, or with $E c o \mathrm{RI}+B a m \mathrm{HI}$, followed by ligation and transfection (Chisholm et al., 1980) into E. coli DHI (recA1 strain kindly provided by D. Hanahan). EcoRIdigested plasmid DNA was treated with calf intestine alkaline phosphatase before ligation to reduce formation of nonrecombinant molecules (Ulrich et al., 1977). Ampicillin-resistant colonies (screened for tetracycline sensitivity when DNA was restricted with BamHI prior to ligation) were checked for inserts by digestion of plasmid DNA prepared from $0.5 \mathrm{ml}$ cultures (Birnboim and Doly, 1979) followed by agarose gel electrophoresis. 


\section{(f) Partial-digestion restriction mapping}

Three subclones of rDNA in pBR322 were used for partial-digestion mapping (Smith and Birnstiel, 1976) of the EcoRI fragment A. 5 to $10 \mu \mathrm{g}$ of DNA from the BamHI-Eco RI clones $\left(\mathrm{pA}_{\mathrm{EB}}, \mathrm{pA} \mathrm{A}_{\mathrm{BE}}\right.$, Fig. 1) was cut at the BamHI or $E c o$ RI site, end-labeled with the appropriate $\left[\alpha^{32} \mathrm{P}\right] \mathrm{dNTPs}$ using reverse transcriptase (Wilson et al., 1981) or DNA polymerase I Klenow fragment (Klenow and Henningsen, 1970), and then cut with $E c o$ RI or BamHI to free the rDNA fragment from the pBR322 DNA. Fragments were loaded into a single well of a $0.8 \%$ low melting temperature agarose gel on a $2^{\prime \prime} \times 3^{\prime \prime}$ glass microscope slide, and electrophoresed in $50 \mathrm{mM}$ Tris $\cdot$ borate, $\mathrm{pH}$ $8.3,1 \mathrm{mM}$ EDTA at $100 \mathrm{~V}$ for $30 \mathrm{~min}$. DNA bands were identified by UV fluorescence after $\mathrm{EtBr}$ staining, wells were cut in front of the fragments desired, and DNA was electrophoresed into the wells at $300 \mathrm{~V}$ for ten 30-s pulses. After each pulse, buffer was removed from a wcll and fresh buffer added. Eluted fractions were monitored for ${ }^{32} \mathrm{P}$ by Cerenkov counting, pooled, and further purified by DEAE. cellulose column chromatography. After ethanol precipitation, fragments were resuspended and digested with various dilutions of enzyme ( 0.001 to 1.0 units $/ \mu \mathrm{g}$ of DNA) for $1 \mathrm{~h}$ at $37^{\circ} \mathrm{C}$. Digested and partially digested DNA was electrophoresed in $1.5 \%$ agarose or $5 \%$ polyacrylamide. ${ }^{32} \mathrm{P}$ end-labeled DNA standards (Sau3A and Hinfl fragments of pBR322, HaeIII fragments of $\phi \mathrm{X174)}$ were run on each gel. Gels were dried onto Whatman paper and autoradiographed as described above.

pA $_{\mathrm{BB}}$ DNA was cut with BamHI, end-labeled as described and recut with $B g l I I$, yielding two labeled rDNA fragments (sec Fig. 1). Conversely, the DNA was cut first with $B g l I I$, and then with $B a m H I$ after end-labeling.

\section{(g) Electron microscopy}

R-loops were formed as described by Thomas et al. (1976). DNA and rRNA at $5 \mu \mathrm{g} / \mathrm{ml}$ each were incubated in $70 \%$ formamide, $85 \mathrm{mM}$ Pipes (piperazine- $N, N^{\prime}$-bis(2-ethanesulfonic acid)) pH 7.8, $10 \mathrm{mM}$ EDTA at $49^{\circ} \mathrm{C}$ for $16 \mathrm{~h}$. Heteroduplex formation was performed using Westmoreland et al. (1969) formamide procedure as described by Davis et al. (1971). Samples were diluted 10 -fold into $70 \%$ formamide,
$100 \mathrm{mM}$ Tris $\cdot \mathrm{HCl}, \mathrm{pH} 8.5,10 \mathrm{mM}$ EDTA, and 40 $\mu \mathrm{g} / \mathrm{ml}$ cytochrome $C$. DNA was spread on a hypophase of $40 \%$ formamide. SV40(II) and M13 DNA were included in each sample as double- and singlestranded DNA standards, respectively.

\section{(h) Enzymes, chemicals and supplies}

Restriction enzymes were purchased from Bethesda Research Labs (BRL), New England Biolabs, or Boehringer. T4 DNA ligase and DNA polymerase I were purchased from BRL. DNA polymerase I Klenow fragment and calf intestine alkaline phosphatase were purchased from Boehringer. DNase I (RNase-free, bovine pancreas) was purchased from Sigma Chemical Co. $\left[\alpha^{32} \mathrm{P}\right]$. dNTPs $(400 \mathrm{Ci} / \mathrm{mmol})$ were purchased from Amersham or New England Nuclear. Chemicals were purchased as follows: agarose and low melting temperature agarose, SeaKem or BRL; polyacrylamide, BRL; CsCl, Kawccki Berylco Industries; NZY amine "A", Humko-Sheffield; XG (5-bromo-4-chloro-3indoyl- $\beta$-D-galactoside), Sigma Chemical Co.; nitrocellulose membranes, Schleicher and Schuell; bacteriological medium, Difco; DEAE-cellulose (DE52), Whatman; electron microscopy supplies, Pelco.

\section{RESULTS}

\section{(a) Identification of recombinants containing rDNA}

Recombinant Charon 16A phage, identified by their colorless phenotype when plated on medium containing the chromogenic XG substrate (Blattner et al., 1977), were picked with sterile capillary tubes and stored in $0.2 \mathrm{ml}$ PSB $(0.1 \mathrm{M} \mathrm{NaCl}, 10 \mathrm{mM}$ Tris . $\mathrm{HCl} \mathrm{pH} 7.5,10 \mathrm{mM} \mathrm{MgCl}, 0.05 \%$ w/v gelatin) in a 96-well microtiter dish. The frequency of colorless recombinants varied from $2-6 \%$ of all plaques. 576 Charon 16A recombinants were picked for screening. Recombinant $\lambda W E S$ phage could not be identified phenotypically, but ligations constructed in parallel without human DNA indicated that the efficiency of ligation events resturing the parental $\lambda \mathrm{gt} W E S \cdot \lambda \mathrm{B}^{\prime}$ (or $\lambda B$ ) phage was small when phage DNA was digested with $E c o$ RI and Sst I. We estimated that $97 \%$ 
of the plaques obtained after transfection were recombinants. 650 of these plaques were also picked and stored in microtiter dishes. A wooden block with 96 straight pins was used to transfer phage from the 96-well microtiter dishes onto lawns of $E$. coli. Incubations at $37^{\circ} \mathrm{C}$ overnight produced lysed areas of 2-5 $\mathrm{mm}$ in diameter. $\lambda W E S$ recombinant phage DNA from lysed areas could be lifted directly onto nitrocellulose filters as described by Benton and Davis (1977). However, Charon 16A DNA did not transfer well using this method, so individual lysed areas were scraped, suspended in $100 \mu \mathrm{l}$ of $0.1 \mathrm{~N} \mathrm{NaOH}$, neutralized with $100 \mu \mathrm{l}$ of $3 \mathrm{M}$ sodium acetate $\mathrm{pH}$ 5.5 , and filtered through nitrocellulose paper under suction, using an epoxy block with 96 holes for the individual lysates. Thirteen Charon 16A clones containing $28 \mathrm{~S}$ rDNA sequences were identified by their hybridization to $28 \mathrm{~S}\left[{ }^{125} \mathrm{I}\right] \mathrm{rRNA}$. Only two of these were stable enough to allow large scale growth, and both of these contained deletions in the vector. Only one clone contained the full-length 7.3-kb EcoRI rDNA fragment A. Both were analysed in detail by electron microscopy (manuscript in preparation).

Five $\lambda W E S$ ribosomal recombinants were identified by their hybridization to ${ }^{32}$ P-nick-translated plasmid DNA containing the rDNA EcoRI fragment A subcloned from the stable Charon 16A recombinant. All five contained the $7.3-\mathrm{kb}$ EcoRI fragment A. DNA prepared from one fetal liver was the source for three of the EcoRI-A fragments cloned in the $\lambda W E S$ vector. A single placenta was the source of DNA for the Charon 16A clones and one of the $\lambda W E S$ clones. The final $\lambda W E S$ clone was derived from a second placental DNA preparation.

\section{(b) Physical map of rDNA clones}

The orientation of the rDNA inserts in both $\lambda$ vectors was determined by digestion with $B a m \mathrm{HI}$, which cuts asymmetrically in the $\lambda$ arms. These orientations were confirmed by heteroduplex formation between DNA from the Charon 16A full-length clone and each of the five $\lambda W E S$ clones. The differences in the two $\lambda$ vectors allowed for recognition of heteroduplex formation and marked the left and right $\lambda$ arms as well as the ends of the cloned human rDNA. The Charon 16A clone and four of the five $\lambda W E S$ clones contain the $E c o$ RI-A fragment in a $3^{\prime}$ to $5^{\prime}$ orientation with respect to the left and right $\lambda$ arms.
A detailed restriction map of the cloned $7.3 \cdot \mathrm{kb}$ EcoRI rDNA fragment A was prepared (Fig. 1). Restriction sites for enzymes cutting once or twice within the IDNA were identified by digestion of the recombinant $\lambda$ DNA, agarose gel electrophoresis, and Southern transfer. These sites were confirmed by digestion of the rDNA subcloned in pBR322. Enzymes that do not cut the cloned rDNA fragment are listed in the legend to Fig. 1. Restriction sites for SmaI and $A l u I$, which each cut many times in the Eco RI fragment A, were mapped by a modification of the Smith and Birnstiel (1976) method using the three subclones of the $A$ fragment in pBR322: $p A_{E B}, p A_{B B}, p A_{B E}$. Sites were determined by labeling one end of the fragment and confirmed by labeling the other end (see MATERIALS AND METHODS). This allowed for more precise measurement of all partial digestion products.

\section{(c) Comparison of rDNA clones from different sources}

Six $\lambda$ clones containing the 7.3-kb EcoRI rDNA fragment $A$ from two tissues of three individuals were compared by restriction digestion and heteroduplex analysis. All cloned fragments produced identical restriction enzyme patterns on agarose and acrylamide gels, even when digested with $A l u I$ and SmaI. Heteroduplexes of the Charon 16A clone against the four $\lambda W E S$ clones in the same orientation showed no visible areas of non-homology within the $7.3 \cdot \mathrm{kb}$ EcoRI fragment.

(d) Identification of gene and transcribed spacer region

The 7.3-kb Eco RI rDNA fragment A contains the $3^{\prime}$ end of the 18S rDNA gene and most of the 28S rDNA. R-looping was used to locate the boundaries between gene and transcribed spacer DNA (Fig. 2). R-loop analysis of $28 \mathrm{~S}$ human $\mathrm{RNA}$ with the rDNA $E c o$ RI fragment A cloned in a plasmid vector reveals $2.7 \mathrm{~kb}$ of DNA duplex within the cloned fragment $\mathrm{A}$, a 4.6-kb R-loop, and a $3^{\prime}$ rRNA tail. The singlestranded rRNA tail was difficult to measure but appeared to be about $500 \mathrm{bp}$ long. A cloned $5.8-\mathrm{kb}$ rDNA BamHI fragment extending from $1.6-\mathrm{kb} 5^{\prime}$ to the EcoRI site, through the end of the 28S rRNA gene, and out into the non-transcribed spacer DNA 


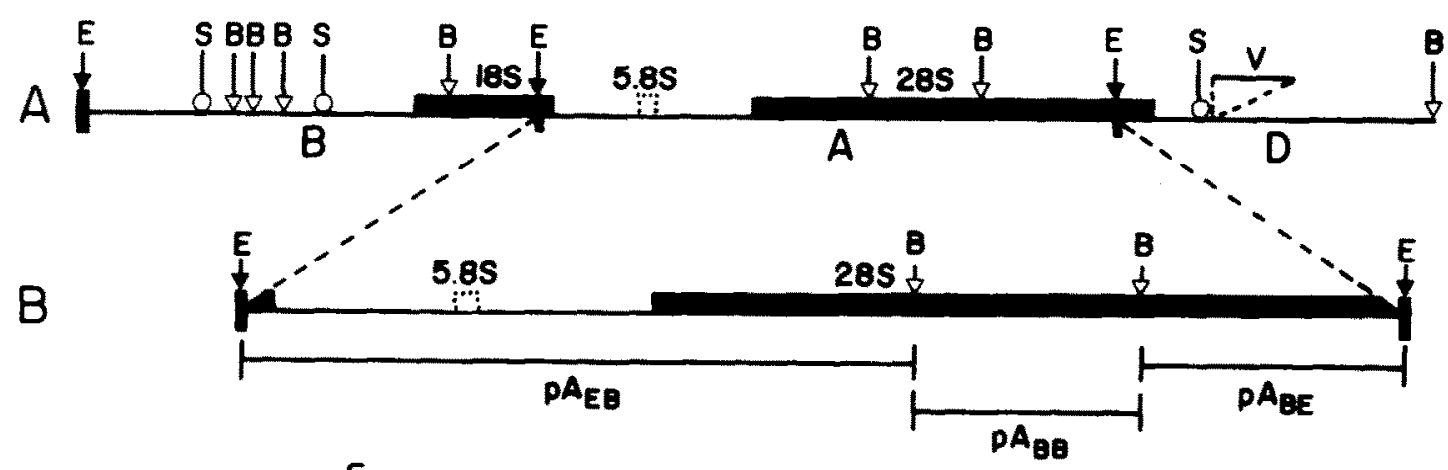

C
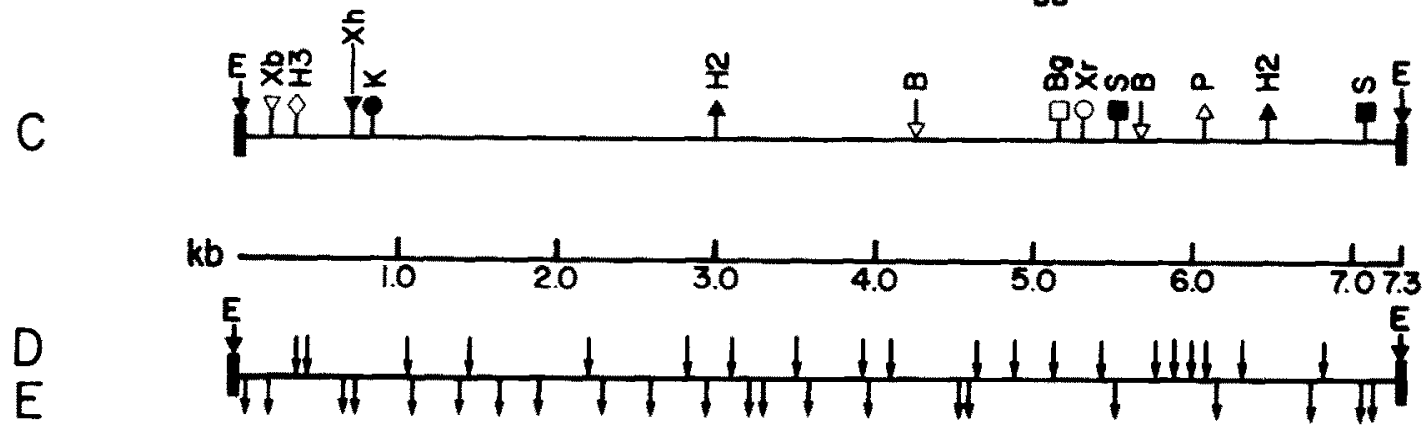

Fig. 1. Restriction map of cloned human rDNA fragments. (A) EcoRI fragments B (Wilson et al., 1978), A, and part of D (for fragment notation see Wellauer and Dawid, 1979), showing EcoRI $(\downarrow), B a m H I(\downarrow)$, and Sall $(\delta)$ restriction sites. Black horizontal bars give the position of sequences coding for the $18 \mathrm{~S}$ and $28 \mathrm{~S}$ rRNAs. The tentative position of the 5.8S rRNA is shown by a dashed box. A variable insert region in the nontranscribed spacer of fragment $D$ is indicated by $V$. (B) Enlargement of the $7.3 \mathrm{~kb} E \mathrm{Eco}$ RI fragment $A$, originally cloned in $\lambda$ vectors and subcloned in pBR322 as illustrated. Notation for plasmid subclones (e.g., pAEB) gives the EcoRI fragment involved, while subscripts indicate restriction sites used for insertion into pBR322, (C) Restriction sites in the 7.3-kb EcoRI fragment A. Numbers are the fragment size in kb from the $5^{\prime} E c o R I$ site: $\downarrow, E c o R I, 0,7.3 ; Y$,

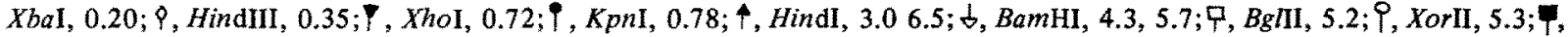
SstI, 5.5, 7.1; 9 , PvuII, 6.1. Enzymes which do not cut in this fragment are BclI, Clal, HpaI, PstI, SalI. (D) Position of SmaI sites in 7.3-kb EcoRI fragment A determined by end labeling and partial digestion mapping (see Material and Methods). From the 5 ' $E c o$ RI site the position of $S m a I$ sites in $\mathrm{kb}$ is: $0.38,0.40,1.07,1.47,2.18,2.81,3.10,3.52,3.92,4.10,4.65,4.88,5.13$ (not indicated by an arrow), $5.14,5.42,5.77,5.89,5.99,6.08,6.32,6.83$. (E) Position of $A$ laI sites in $7.3-\mathrm{kb} E c o$ RI fragment A, determined as in ID. Numbers represent size of fragments, in $\mathrm{kb}$, from $5^{r}$ EcoRI site: $0.05,0.20,0.68,0.71,1.10,1.40,1.65,1.90$, $2.30,2.61,2.95,3.21,3.31,3.58,3.96,4.52,4.55,5.12$ (not indicated by an arrow), $5.52,6.14,6.74,7.06,7.11$.

(manuscript in preparation), was R-looped to confirm the $3^{\prime}$ endpoint of the $28 \mathrm{~S}$ rDNA. The R-loop measured was $2.1 \mathrm{~kb}$, indicating that the $3^{\prime}$ end of the gene lies about 500 bp beyond the EcoRI site. The $3^{\prime}$ end of the $18 \mathrm{~S}$ rDNA was positioned by R-loop analysis of the $5.7-\mathrm{kb} E c o$ RI fragment B (Wilson et al., 1978) and of a $5.3-\mathrm{kb}$ BamHI fragment cloned in pBR322 that extends from the BamHI site in the $18 \mathrm{~S}$ rDNA to the $5^{\prime}$ most BamHI site in the 28S rDNA (clone designated $\mathrm{pBA}_{\mathrm{BB}}$ ). Sizes of all R-loops obtained are indicated in Fig. $2 \mathrm{C}$. The presence of the 5.8S rDNA in our cloned fragment $\mathrm{A}$ was confirmed by identification of the $5.8 \mathrm{~S}$ gene by DNA sequencing. The position of the $5.8 \mathrm{~S}$ rDNA has been tentatively assigned (Fig. 1) by comparison of detailed restriction sites found in the internal transcribed spacer with sites predicted from the known HeLa 5.8S rRNA sequence (Khan and Maden, 1977).

\section{(e) Comparison of cloned rDNA fragments with genomic rDNA}

Restriction-enzyme digestion of human genomic DNA, followed by agarose gel electrophoresis, transfer of DNA to nitrocellulose paper, and hybridization with the cloned rDNA fragments has shown considerable conservation of the restriction patterns within the transcribed rDNA sequences. One major exception is the HinclI site toward the $3^{\prime}$ end of the EcoRI fragment A. Genomic blotting of HinclI- 


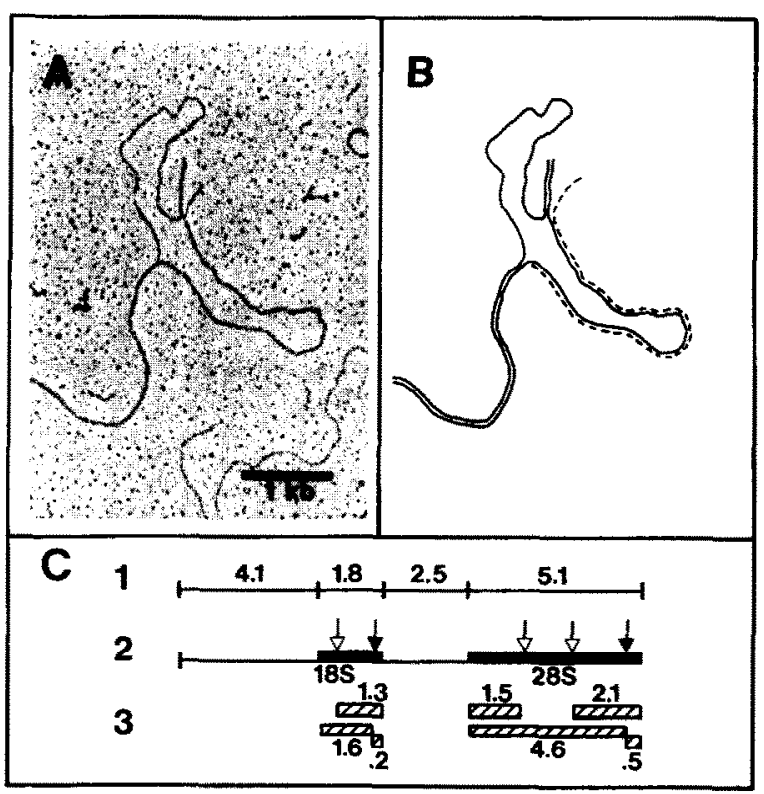

Fig. 2. R-looping of cloned human IDNA with $18 \mathrm{~S}$ and $28 \mathrm{~S}$ human $\mathrm{rRNA}$. (A) Electron micrograph of R-loop between recombinant plasmid $\mathrm{pA}$ (pBR322 containing the $7.3-\mathrm{kb}$ $E c o$ RI rDNA fragment A and human 29S RNA. pA DNA was cut at the Sall site before R-looping. (B) Tracing of R-looped molecule in 2A. Dashed line indicats $28 \mathrm{~S}$ rRNA. Single solid line represents the single rDNA strand displaced by the TRNA. Solid double lines are double-stranded DNA (both vector and EcoRI fragment A sequences not found in the mature 28S rRNA). The short, unpaired rRNA corresponds to the $3^{r}$ end of the 28S rDNA not contained in the Eco RI fragment $A$. (C) Sizes of gene and spacer regions identified by R-looping. (1) Sizes of gene and spacer regions (obtained from R-loops in $\mathrm{C} 3$ ): $4.1 \mathrm{~kb}$, external $3^{\prime}$ spacer; $1.8 \mathrm{~kb}, 18 \mathrm{~S}$ rDNA; $2.5 \mathrm{~kb}$, internal transcribed spacer; $5.1 \mathrm{~kb}, 28 \mathrm{~s}$ INA. (2) Location of $18 \mathrm{~S}$ and $28 \mathrm{~S}$ rDNA coding sequences (black bars), and restriction sites used for subeloning IDNA in pBR322 prior to R-looping. $\downarrow$ BamHI, $\downarrow$ EcoRI. (3) Size of R-loops (kilobase pairs) and rRNA tails (kilobases) measured on R-looped molecules as follows:

\begin{tabular}{|c|c|c|c|c|}
\hline \multirow[t]{2}{*}{ Subclone } & \multicolumn{2}{|c|}{ 18S rRNA } & \multicolumn{2}{|c|}{$28 \mathrm{~S}$ rRNA } \\
\hline & R-loop & rRNA tail & R-loop & rRNA tail \\
\hline $\begin{array}{l}\mathrm{pBA}_{\mathrm{BB}}{ }^{\mathrm{b}} \\
\mathrm{pB}\end{array}$ & $\begin{array}{l}1.3 \\
1.6\end{array}$ & $\begin{array}{l}\text { a } \\
0.2\end{array}$ & 1.5 & a \\
\hline $\mathrm{pAD}_{\mathrm{BB}} \mathrm{c}$ & & & $\begin{array}{l}4.6 \\
2.1\end{array}$ & $\begin{array}{l}0.5 \\
\mathbf{a}\end{array}$ \\
\hline
\end{tabular}

a Not measured.

${ }^{b} \mathrm{pBA}_{\mathrm{BB}}$ : pBR322 containing $5.3-\mathrm{kb}$ BamHI fragment from BamHI site in $18 \mathrm{~S}$ gene to $5^{\prime}$ most BamHI site in $28 \mathrm{~S}$ gene (see C2).

$c_{\text {pAD }}$ BB: pBR322 containing $5.8-\mathrm{kb}$ BamHI fragment extending from $3^{\prime}$ most BamHI site in the EcoRI fragment A to $5^{\prime}$ most BamHI site in the EcoRI fragment D.

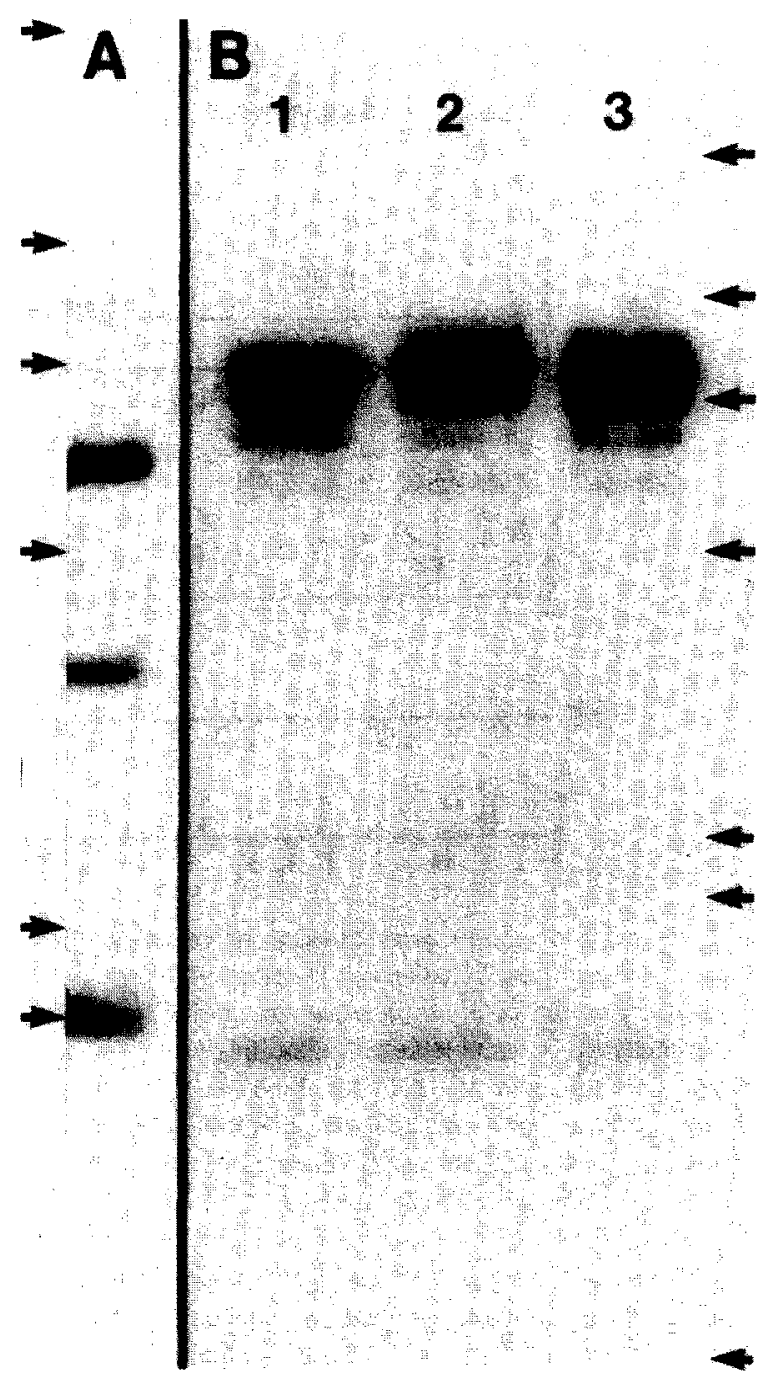

Fig. 3. Agarose gel electrophoresis of restriction endonuclease-digested human DNA transferred to nitrocellulose paper (Southern, 1975) and hybridized to ${ }^{32}$ P-nick-translated cloned human IDNA ( $\mathrm{PA}_{\mathrm{BE}}$ ). $5 \mu \mathrm{g}$ of human DNA prepared from white blood cells was digested with 5 units of restriction endonuclease for $1 \mathrm{~h}$ at $37^{\circ} \mathrm{C}$, heated at $65^{\circ} \mathrm{C}$ for $5 \mathrm{~min}$, and electrophoresed through a $1 \%$ agarose gel in 40 $\mathrm{mM}$ Tris $\cdot \mathrm{HCl}, 1 \mathrm{mM}$ Na-acetate, $1 \mathrm{mM}$ EDTA, pH 8.2. Position of $\lambda$ HindIII fragments used as size markers are indicated by arrows as follows, from top to bottom: $23.72,9.46,6.67$, $4.45,2.25,1.96,0.59 \mathrm{~kb}$. (A) Hincll-digested human DNA. Hybridizing bands are seen at $1.8,3.5$, and $5.3 \mathrm{~kb}$ (see Fig. $1 C$ for positions in fragment A). (B) BamHI-digested human DNA from parents and offspring. Hybridizing bands are seen in all lanes at $7.6,6.7,5.8,4.9$, and $1.2 \mathrm{~kb}$. Lane 1 , Mother. Lane 2, Father. Lane 3, offspring. 8.5 and $16.0 \mathrm{~kb}$ bands are present in father and child but not in mother.

digested human DNA and hybridization to $28 \mathrm{~S}$ $\left[{ }^{125} \mathrm{I}\right] \mathrm{rRNA}$ or ${ }^{32} \mathrm{P}$-nick-translated Eco RI fragment A reveals a heterogeneity in this site (Fig. 3A). From 
the intensity of the bands, it appears that in about $50 \%$ of the rDNA this HincII site is absent, producing an additional DNA fragment that is $5.3 \mathrm{~kb}$ (see Fig. 1). All six cloned EcoRI fragments contain this HinclI site.

Genomic blotting of BamHI-digested human DNA and hybridization with the ${ }^{32} \mathrm{P}$-labeled subclone $\mathrm{pA}_{\mathrm{BE}}$ reveals a polymorphism in the nontranscribed spacer region. Six bands are seen regularly in most individuals (Fig. 3B). Five of these fragments vary in length by about $900 \mathrm{bp}$ and range from about 5 to $9 \mathrm{~kb}$ in length. This same type of heterogeneity is also seen when the DNA is digested with BglII (Schmickel et al., 1980). In addition, certain families exhibit other variant BamHI fragments (Fig. 3B, lanes 2-3). No variability is observed when genomic DNA is digested with both EcoRI and BamHI prior to hybridization with ${ }^{32} \mathrm{P}$-labeled $\mathrm{pA}_{\mathrm{BE}} \mathrm{DNA}$, and the size of the BamHI-EcoRI genomic fragment corresponds to that cloned in $\mathrm{pA}_{\mathrm{BE}}$.

\section{DISCUSSION}

The cloning of human rDNA sequences isolated from different tissues and individuals has allowed the first direct and detailed comparative analysis of this family of genes. We initially chose to clone the Eco RI rDNA fragments in Charon 16A. The $5.7 \cdot \mathrm{kb}$ $E c o$ RI fragment B had been cloned in this same vector with no difficulty (Wilson et al., 1978), but the 7.3-kb Eco RI fragment A was unstable in Charon 16A. From 13 clones identified by hybridization to $28 \mathrm{~S}\left[{ }^{125} \mathrm{I}\right] \mathrm{rRNA}$, we were able to isolate only one that containcd a stable, full-length $E c o$ RI fragment $\mathbf{A}$. We cannot rule out the possibility that the instability of this fragment $\mathrm{A}$ in Charon $16 \mathrm{~A}$ is related to specific rDNA sequences, but since the stable, fulllength clone contains deletions in the vector, and since one other stable clone contains deletions in both vector and insert, we suspect that the size of the 7.3-kb fragment cloned in Charon $16 \mathrm{~A}$ is responsible for the observed instability. All of the five $\lambda W E S$ recombinants containing the 7.3-kb rDNA Eco RI-A fragment are stable, and none of the phage have any observable deletions. This finding is consistent with the supposition that the instability in the lambda Charon vector was due to rDNA fragment size and was not a property of the IDNA sequence.

The six $\lambda$ clones containing rDNA EcoRI fragment $\mathrm{A}$ were derived from three individuals and two types of tissue as previously indicated. Detailed restriction mapping of these clones and heteroduplex analysis reveal no differences between any of the cloned fragments, either in the genes or in the internal transcribed spacer regions. At this level of resolution, then, there is a conservation of sequence in the transcribed rDNA. In humans, the rDNA repeats are located on the five acrocentric chromosomes Nos. 13, 14, 15, 21, and 22, and while our procedure does not allow identification of the original chromosal location of the fragments isolated by cloning, probability would dictate that our isolated genes are derived from more than one chromosome. The fact that we see no differences in clones isolated from different individuals and tissues indicates a remarkable mechanism for conservation of these rDNA sequences within and between individuals. One exception to this conservation within transcribed rDNA is a HincII site variability. And, while about $50 \%$ of genomic DNA appears to be missing the 3 '-most HincII site in the 28S rRNA (Fig. 3A), all six of the cloned fragments contain this site. Although the small sample size may be responsible for this discrepancy, modification of the genomic DNA is an alternative explanation. Methylation of the cytosine of a $\mathrm{CpG}$ doublet in eukaryotic DNA is a widespread phenomenon (Grippo et al., 1968) and has been suggested as a means of inactivating transcription of rDNA sequences (Tantravahi et al., 1981). Since the HincII recognition site is GTPyPuAC, insertion of $\mathrm{CpG}$ for the PyPu sequence results in a SalI recognition site (GTCGAC). However, none of our cloned fragments are cut by SalI. It is possible that another type of eukaryotic DNA modification is responsible for the variation seen in genomic DNA but not in the cloned fragments.

Genomic blotting of BamHI or BglII-digested DNA and hybridization to ${ }^{32} \mathrm{P}$-labeled $\mathrm{pA}_{\mathrm{BE}}$ reveals an interesting polymorphism in the rDNA (Fig. 3B). Since this is not seen with the BamHI-Eco RI digestion and since our cloned fragments are identical, we know this variability lies beyond the $3^{\prime}$ Eco RI site in the 28S rDNA. The polymorphism can be explained by a DNA fragment of discretely variable length inserted between the EcoRI site and the BamHI site in the nontranscribed spacer rDNA. This possibility is 
depicted in Fig. 1 and is consistent with restriction digestion and heteroduplex analysis of Bam HI fragments recently cloned in Charon 27 , which extend past the end of the 28S rDNA gene and into the nontranscribed spacer region (J.M. Erickson and R.D. Schmickel, manuscript in preparation). Similar heterogeneity in the nontranscribed spacer rDNA has been observed in R-looped preparations of genomic human DNA (Wellauer and Dawid, 1979). Thus, in contrast to the strong conservation of sequence within the transcribed rDNA, we see a marked but apparently regular heterogeneity in the length of nontranscribed spacer rDNA. Although this variation has been previously described, the construction of a plasmid subclone containing the $3^{t}$ end of the EcoRI fragment $\mathrm{A}$ has permitted us to examine more closely the polymorphism of the spacer region adjacent to the $3^{\prime}$ end of the $28 \mathrm{~S}$ gene. In addition to the four bands already noted (Schmickel et al., 1980; Arnheim et al., 1980a), hybridization of BamHI-digested DNA with ${ }^{32} \mathrm{P}$ labeled $\mathrm{pA}_{\mathrm{BE}}$ DNA (Fig. 3B) reveals a 4.9-kb band. This new band is about $900 \mathrm{bp}$ smaller than the next larger band, and seems to be part of the series of frag. ments that differ from each other by the same increment. One other BamHI band detected in all blots, using the ${ }^{32} \mathrm{P}$-labeled $\mathrm{pA}_{\mathrm{BE}}$ DNA probe, is 1.2 $\mathrm{kb}$ and is present in all tissues examined (spleen, placenta, leukocytes). This may represent an end unit in a tandem series, or the presence of rDNA sequences located elsewhere in the genome (Arnheim et al., 1980b; Childs et al., 1981). In certain individuals, other BamHI restriction fragments are seen, and are often transmitted to offspring (Fig. 3B). These fragments may arise through infrequent events but, once generated, may be rather stable in the germ line. This phenomenon has been observed in genomic blots from several mother-father-offspring sets (unpublished results).

R-looping and restriction mapping of our cloned rDNA fragments have allowed the positioning of the mature $18 \mathrm{~S}$ and $28 \mathrm{~S}$ rDNA sequences within the ribosomal repeat, as well as the tentative location of the $5.8 \mathrm{~S}$ human rDNA. These assignments have been quite useful, and various cloned fragments are being studied in relation to human IRNA processing (Dranginis et al., 1980). Nucleotide sequencing of cloned rDNA fragments is in progress and should help clarify (i) sequences pertinent to control of
rDNA transcription and processing, (ii) the extent of homology between cloned rDNA fragments within and between individuals and tissues, (iii) the basis for the Hincll variation in genomic rDNA, and (iv) the molecular basis for the regular heterogeneity observed in nontranscribed spacer rDNA.

\section{ACKNOWLEDGEMENTS}

We thank Dr. J.W. Beard, Life Sciences Research Laboratories, for kindly providing AMV reverse transcriptase, and Mechthilde Knoller for excellent technical assistance. This research was supported by the National Institutes of Health Program Project Grant No. HD13506-03 to RDS and GNW. DJD and JME are supported by NIH Genetics Training Grant No, 1-T32-GM-07544-03.

\section{REFERENCES}

Arnheim, N., Krystal, M., Schmickel, R., Wilson, G., Ryder, O. and Zimmer, E.: Molecular evidence for genetic exchanges among ribosomal genes on nonhomologous clurumosomes in man and apes. Proc. Natl. Acad. Sci. USA 77 (1980a) 7323-7327.

Arnheim, N., Seperack, P., Banerji, J., Lang, R., Miesfeld, R. and Marcu, K.: Mouse rDNA non-transcribed spacer sequences are found flanking immunoglobulin $\mathrm{C}_{\mathrm{H}}$ genes and elsewhere throughout the genome. Cell 22 (1980b) 179-185,

Benton, W.D. and Davis, R.W.: Screening $\lambda g t$ recombinant clones by hybridization to single plaques in situ. Science 196 (1977) 180-182.

Birnboim, H.C. and Doly, J.: A rapid alkaline extraction procedure for screening recombinant plasmid DNA. Nucl. Acids Res. 7 (1979) 1513-1523.

Blattner, F.R., Williams, B.G., Blechl, A.E., DennistonThompson, K., Faber, H. E., Furlong, L., Grunwald, D.J. Kiefer, D.O., Moore, D.D., Schumm, J.W., Sheldon, E.L. and Smithies, O.: Charon phages: Safer derivatives of bacteriophage lambda for DNA cloning. Science 196 (1977) $161-169$.

Bolivar, F., Rodriguez, R.L., Greene, P.J., Betlach, M.C., Heyneker, H.L. and Boyer, H.W.: Construction and characterization of new cloning vehicles, II. A multipurpose cloning system. Gene 2 (1977) 95-113.

Childs, G., Maxson, R., Cohn, R.H. and Kedes, L.: Orphons: Dispersed genetic elements derived from tandem repetitive genes of eucaryotes. Cell 23 (1981) 651-663. 
Chisholm, R.L., Deans, R.J., Jackson, E.N., Jackson, D.A. and Rutila, J.E.: A physical gene map of the bacteriophage P22 late region: Genetic analysis of cloned fragments of P22 DNA. Virology 102 (1980) 172-189.

Davis, R.W., Simon, M., Davidson, N.: Electron micoscope heteroduplex methods for mapping regions of base sequence homology in nucleic acids, in Grossman, $L$. and Moldave, K. (Eds.), Methods in Enzymology, Vol. 21. Academic Press, New York, 1971, pp. 413-428.

Denhardt, D.T.: A membrane-filter technique for detection of complementary DNA. Biochem. Biophys. Res. Commun. 23 (1966) 641646.

Dranginis, A., Szura, L., Erickson, J., Dorney, D.J., Schmickel, R.D. and Wilson, G.: Structure and expression of human ribosomal genes. Fed. Proc. 39 (1980) 1745.

Grippo, P., Laccarino, M., Parisi, E. and Scarano, E.: Methylation of DNA in developing sea urchin embryos. 1 . Mol. Biol. 36 (1968) 195-208.

Henderson, A.S., Warburton, D. and Atwood, K.C.: Location of ribosomal DNA in the human chromosome complement. Proc. Natl. Acad. Sci. USA 69 (1972) 3394-3398.

Khan, M.S.N. and Maden, B.E.H.: Nucleotide sequence relationships between vertebrate $5.8 \mathrm{~S}$ ribosomal RNAs. Nucl. Acids Res. 4 (1977) 2495-2505.

Klenow, $H$. and Henningsen, 1 .: Selective elimination of the exonuclease activity of the DNA polymerase from $E$. coli B by limited proteolysis. Proc. Natl. Acad. Sci. USA 65 (1970) 168-175.

Krystal, M. and Arnheim, N.: Length heterogeneity in a region of the human ribosomal gene spacer is not accompanied by extensive population polymorphism. J. Mol. Biol. 126 (1978) 91-104.

Leder, P., Tiemeier, D. and Enquist, L.: EK2 derivatives of bacteriophage lambda useful in the cloning of DNA from higher organisms: The $\lambda g t W E S$ system. Science 196 (1977) 175-177.

Long, E.O. and Dawid, I.B.: Repeated genes in eucaryotes. Annu. Rev. Biochem. 49 (1980) 727-764.

Perry, R.P.: Processing of RNA. Annu. Rev. Biochem. 45 (1976) $605-629$.

Rigby, P.W., Dieckmann, M., Rhodes, C. and Berg, P.: Labelling DNA to high specific activity in vitro by nick translation with DNA polymerase I. J. Mol. Biol. 113 (1977) 237-251.

Schmickel, R.D.: Quantitation of human ribosomal DNA: Hybridization of human DNA with ribosomal RNA for quantitation and fractionation. Pediat. Res. 7 (1973) 5-12.

\section{NOTE ADDED IN PROOF}

Since the submission of this work for publication, we have improved the resolution of small DNA fragments on a $4-8 \%$ gradient polyacrylamide gel and
Schmickel, R.D. and Knoller, M.: Characterization and localization of the human genes for ribosomal ribonucleic acid. Pediat. Res. 11 (1977) 929-935.

Schmickel, R.D., Waterson, J.R., Knoller, M., Szura, L.L. and Wilson, G.N.: HeLa cell identification by analysis of ribosomal DNA segment patterns generated by endonuclease restriction. Am. J. Hum, Genet. 32 (1980) 890-897.

Smith, H.O. and Birnstiel, M.L.: A simple method for DNA restriction site mapping. Nucl. Acids Res. 3 (1976) 2387-2398.

Southern, E.M.: Detection of specific sequences among DNA fragments separated by gel elcetrophoresis. J. Mol. Biol. 98 (1975) 503-517.

Steffensen, D.M. and Duffey, P.: Localization of $5 S$ ribosomal DNA genes on human chromosome 1. Nature 252 (1974) 741-743.

Tantravahi, U., Breg, W.R., Wertelecki, V., Erlanger, B. and Miller, O.J.: Evidence for methylation of inactive human rRNA genes in amplified regions. Hum. Genet. 56 (1981) 315-320.

Thomas, M., White, R.L. and Davis, R.W.: Hybridization of RNA to double-stranded DNA: Formation of R-loops. Proc. Natl. Acad. Sci. USA 73 (1976) 2294-2298.

Tiemeier, D.C., Tilghman, S.M. and Leder, P.: Purification and cloning of a mouse ribosomal gene fragment in coliphage lambda. Gene 2 (1977) 173-191.

Ullich, A., Shine, J., Chirgwin, J., Pictet, R., Tischer, E., Rutter, W.J. and Goodman, H.M.: Rat insulin genes: construction of plasmids containing the coding sequences. Science 196 (1977) 1313-1319.

Wellauer, P.K. and Dawid, I.B.: Secondary structure maps of RNA: Processing of HeLa ribosomal RNA. Proc. Nat1. Acad. Sci. USA 70 (1973) 2827-2831.

Wellauer, P.K. and Dawid, I.B.: Isolation and sequence organization of human ribosomal DNA. J. Mol. Blol. 128 (1979) 289-303.

Westmoreland, B.C., Szybalski, W. and Ris, H.: Mapping of deletions and substitutions in heteroduplex DNA molecules of bacteriophage lambda by electron microscopy. Science, 163 (1969) 1343-1348.

Wilson, G.N., Hollar, B.A., Waterson, J.R. and Schmickel, R.D.: Molecular analysis of cloned human $18 S$ ribosomal DNA segments. Proc. Natl. Acad. Sci. USA 75 (1978) 5367-5371.

Wilson, G.N., Szura, L.L., Rushford, C.L., Jackson, D.A. and Erickson, J.M.: Structure and variation of human ribosomal DNA: the external transcribed spacer and adjacent regions. Am. J. Hum. Genet., 33 (1981) in press.

Communicated by H.O. Smith.

find that digestion of one of the cloned $E c o$ RI A fragments with $S m a l$ produces a band that is 3 bp larger than the comparable SmaI band found in the other five cloned $\mathrm{A}$ fragments. 